from Mr: Severn contains the following passage :- “My present motive is to draw your attention to the injustice done you in the 7) Argus business; I have of course read all your letters in the Monthly Notices of the R.A.S. on the "subject. You must not allow the Spectator, or Mr. Le Sueur, or any other man to deprive you of your discovery; you have at least done, and that years ago, what the $4 \mathrm{ft}$. Cassegranians and Mr. Le Sueir are claiming as their discovery. I can't stand this, and therefore if you don't defend yourself, by writing to our papers, I must. I send you a Leader with my paper in it, also another re ๆ."

On reading these two extracts, which are dated about the same time, it will appear that the writer must have very suddenly changed his mind.

In June 1869 I visited Melbourne for the purpose of seeing the new large refiecting telescope, and must confess to being much surprised on seeing the object $\eta$ Argus in such a small field with so large an instrument. Mr. Le Sueur thought at the time that he saw a faint shadow of a lemniscate; and what I saw was a dark path across the nebula, not unlike that portion of Eridanus, occupied by 188 and 198 l. C. and not far from the star Achernar. The object was only seen between passing clouds, and although the best speculum was in the instrument at the time, the definition was not good.

In June 1862 I brought before this Society a copy of the drawing made from observations on that beautiful cluster of coloured stars known as ic Crucis, the original drawing, \&c, of which was at the time remitted to the Royal Astronomical Society, with notes on the variation of both colour and position when compared as eye drafts, with Sir John Herschel's observations made at the Cape of Good Hope. (Vide Monthly Notices, R.A.S., Vol. 23, p. 32.)

As the instrument used at the Cape was in every respect different from the one used in Hobart Town, and the effect of colour varying, as it does, so much in different persons, I disconinted observing to allow time for other changes to become known, and have now waited nearly nine years, in order to compare the object with the previous drawing by the same optical means. Sir John Herschel estimated this chister to be formed of from 50 to 100 stars; in the drawing of 1862 , a copy of which now lies on the table, there were laid down 75 stars to which the colour of each was given. It is now known that certain alterations have taken place since 1862 , but a series of clondy nights has prevented the possibility of preparing a sequent to the former drawing in time for the present meeting.

F. Аввотт

\section{SCIENTTFIC SERIALS}

Tratisactions of the Ninibchester Geoiogical Society. Vol. ix., Parts I, 2, and 3; Vol. x., Part I. We have in these first three parts the President's Address and the papers read before the society during the session $1869 * 70$. The papers are twelye in number, and embrace a variety of topics. Mr. Boyd Dawkins gives an account of some explorations in the Denbighshire caves. In one of these a large quantity of human bones was found intermingled with remains of horse, goat, hare, rabbit, badger, large birds, wolves, wild cats, foxes, and Celtic shorthorns, roe and red deer. $\mathrm{He}$ is of opinion that this cave has been used as a burial place at different times in the preRoman era. The skulls found belong to that type which Professor "Fuxley terms the "river bed skull," and the tibie indicated the platycnemic character or the bandy-leggeduess of the people to whom they belonged. There are other three papers on jalreontological subjects - "Oiz a Specimen of "Homalonotus Delphino-cephalus," by Mr: Edward Holber; "On some Starfishes from the Rhenish Devonian Strata," by Mr. J: Eccies, and "On two Species of Productus," by the same author. To these may be added another by the president, Mr. T. Aitken, "On the Pholasboring Cort troversy," in which the author conclucles, against the notion upheld by Mr. Macintosh, that the holes found in the faces of certain limestone rocks at many different levels, even as high as 1,435 feet above the sea, have been bored by phulades during a period of submergence. He inclines to the belief that the holes have been formed by land molluscs, as originally suggested by Dr. Buckland. There are several paper's un physical geology, which will repay perusal. The longest of these is one by Mr. Spencer, "On the Millstone-Grit Rocks" of Halifax, which will be of use as a guide to that locality. The author distinguishes four beds of grit separated by intervening thick shales. Lists of fossils are given, and these-are not so meagre as one might have expected. Mr. J. Curry has a paper "On the Throw of the Pennine Fault," which he thinks is not so great as is commonly believed. Some interesting "Observations on the Temperatures at the Pendleton Colliery," by Mr. J. Knowles, are sure to be frequently referred to. "On some of the Causes of the Different Modes of Working and Ventilating Coal Mines," by Mr. Warburton, contain some wholesome criticism. He maintains "that the systems of working coal, as at present practised, clo not depend upon the nature or condition of either the coal or the roof, but upon the mining education of those who have the management." Difficulties in the way of ventilation arise from ignorance and from the modes of working often interfering with well-known natural laws. Other papers in Vol. ix. are "On the Use of Gunpowcler in Mines," by Mr. Greenwell ; "On two Dykes in North Lancashire," by Mr. Eccles; and "Observations on some Specimens of Silver Ore from United States," by Mr. Fletcher. Part r. of Vol. x. is occupied for the most part with the President's address, in. augurating the session 1870-7 I. Mr. Aitken treats of our coal supply in its various aspects, and a number of other, chiefly palæontologicat, topics. The other communications in this part do not call for any special remark. They are three in number, viz., "The Spirorbis Limestone in the Forest of Wyre Coal Field," by D. Jones; "On Faults in Drift," by J. Aitken; and" "On the Underground Conveyance of Coals," by G. C. Greenwell. We are glad to see from the report of the Council that the Society is fourishing, and that the number of contributors to the Transactions is increasing.

Verhandhungen derk. k. geologischen ReichsanstaltzuWien. Nos. 8 and 9 (1 $87 \mathrm{I}$ ). No. 8 contains the usual short summaries of papers and reports, among which may be mentioned one on the last earthquake and the hotsprings and solfataras at Milo ; and another on the Tertiary Land-fauna of Central Italy, by E. Suess. The other papers are more of local interest, but a number of useful analyses of minerals is given. Among the notices of contempo. rary publications is one of a work by Dr. Prestel, on the Climatal and other Changes which the Coasts of the North Sea have undergone since Glacial Times. In No. 9 will be found a short account of a Coast Survey of the Adriatic Sea. The survey when completed will, it is expected, make the bed of this sea as well known as that of any other which has been explored. The bottom of the south basin of the Adriatic is covered throughout, it would seem, with a yellow sludge or slime, which is brought down by the large rivers of Albania. In this same area a re. markable rocky plateau rises up from the slimy sea-bed, at a depth of from 325 to 370 fathoms to within 100 fathoms of the surface. Some details of other parts of the sea bottom are given. The number contains several other reports, among which we find some account of the Library of the Institute, which would appear to be in a flourishing condition. The usual literary notices and lists of books received conclude the number.

\section{SOCIETIES AND ACADEMIES LONDON}

Royal Microscopical Society, October 4.-Mr. W. Kitchen Parker, F.R.S., President in the chair. The first meeting of the session was held on Wednesday evening. Mr. Parker contributed a valuable paper "On the Development of the Facial Arches of the Embryo Salmon," at the conclusion of which he expressed his opinion that the development of the brain case of the osseous fishes demonstrates that group to be much closer allied to the Sauropsida, or Birds and Reptiles, than it is to that of the Batrachia, or Frog tribe. Mr. Parker highly enlogised the use of chromic acid as a medium for hardening without distorting the substance of the brain when required for secitons. - Dr. Spencer Cobbold handed in a report on some preparations of En:ozoa with accom. panying notes, forwarded to the Society by Mr. Morris, of Sydney, and made observations on some of the most interesting forms. Of the five species collected by Mr. Morris, Dr. Cobbold stated that by far the greatest amount of importance was to be attached to the discovery in Australia of Stephamurus dentatzes. This Entozoan was introduced to the scientific world as early as the year 1834 by Nasterer, who found it in large quantities infesting the adipose tissuies of a breed of Chine:se pigs, on the Rio Negro in Brazil. Up to the year I870 nothing further was heard of this parasite, when Dr. Cob. bold received a communication from Prof. Fletcher, of New 
York, stating that it was committing great destruction among the pork-raising districts of the United States, thousands of pigs in some localities falling victims to its ravages. In aspect and structure Stephanzunes bears a close resemblance to Trichint, but is of much larger size, the cysts of the former frequently measuring an inch or an inch and a hilf in length; its greater magnitude is the principal safeguard against its introduction into the human subject. Dr. Cobbold supplemented his remarks with some observations on the question of sewage irrigation connected with the propagation of entozoic diseases. In his opinion it played a very important part, and he did not feel his position in the slightest degree destroyed from the fact of Mr. Hope's ox brought up for nearly two years on the produce of the "Breton" irrigated farm being entirely free from internal parasites of any kind. This animal had never been allowed to graze, but had had all its food cut and carried to it; its water was all brought to it, and altogether the animal had been so carefully guarded and nurtured that the Entozoa were shut out from any chance of obtaining a foo hold. 'The soil, again, on Mr. Hope's estate was of such a porous rature that the matter containing the undeveloped germs was at once absorbed, while on swampy ground, as instanced about Croydon and other low-lying districts, where this mode of irrigation was practised, the roots of the grasses were constantly immersed in it. The prevalence of tape-worm and other entozoic diseases in those parts of India where sewage irrigation is carried out, is enormous, and thousands of cattle are destroyed as being unfit for human food. This wanton destruction of all carcases containing traces of Cysticercus, or other Entozoa, Dr. Cobbold severely censured, as the meat, on being thoroughly cooked, even though infested with parasites, is wholesome, free from any abnormal taste, and its consumption is unattended by deleterious results.

\section{PARIS}

Academie des Sciences, September 25. -M. Faye in the chair. M. Dumas, the perpetual secretary, gave many interesting details of a report writen by a committee of which he is a member, describing the Phylloxera vastatrix, the pest of the vine. A prize of $400 \%$. was offered for its destruction by the French Government, and will be awarded in 1873 . But two candidates have invented means which appear to be good. M. Faucon has suggested putting the whole vine garden under water for two days, which is sufficient to suffocate the insects with injuring the plant itself. When it is impossible to inundate, M. Blanthou suggested to water with a liquid composed of I,O00 parts water and one of impure phenic acid.-M. M. Fonssagrives has discovered that the mouldiness of Roquefort cheese, which is eaten by French gourmets only in a state of putrefaction, when placed on a piece of bread, developes the Oidium aurantiacum, which may account for the abundant appearance of this pest last summer.-M. Dumas reported upon the results obtained by microscopical selection, as suggested by $M$. Pasteur and practised by many French silkworm brceders for curing the silkworm plague known as pébrine. The results are magnificent, and the plague may now be consi. dered as almost entirely suppressed. Last year one-tenth of the French silkworm breeders used the method invented by $M$. Fasteur, and the use of it will be almost universal in the course of a few years. - M. Grimaud of Caux, one of the veteran members of the Parisian scientific press, rearl a memoir "On the Smoke of Locomotives in the Mont Cenis Tumnel." M. Grimand finds it to be a great objection, and to require much caution. But such is not the advice of people who are fresh from the tunnel. - M. Philips read a long paper, by a gentleman wbo does not belong to the Instiute, "On the Integration of some Special Differential Linear Equations." He commented largely upon the paper, which he finds worthy of much consideration. New communications "On the Spectrum Aralogies of Simple Bodies" were also read.

\section{PHILADELPHIA}

Academy of Natural Sciences, January 3.-Mr. W. M. O. Vaux, vice-president, in the chair. Prolessor O. C. Marsh, of Yale College, exhibited a tooth of a new species of Lophicdon, from the Miocene of New Jersey, which was the first indication yet discovered of remains of the Tapiride on the Atlantic coast, or of the genus Lophiodon in this country, east of the Rocky Mountain region. The tooth, which was in a perfect state of preservation, was the first true molar of the left upper jaw. It measured across the crown seven lines in antero-posterio diameter, and eight and one-quarter lines in transverse diameter. This would indicate an animal intermediate in size between $L$. occidentalis and L. modestus of Dr. Leidy. From the latter species it may readily be distinguished by the enamel of the crown, which is smooth and not wrinkled. As this species is evidently distinct from any described, Prof. Marsh proposed for it the name Lophiodon validzs. 'The specimen was found in the miocene marl of Cumberland Comnty, New Jersey, and apparently at about the same horizon as the Elotheriatm Leidyanzm, and Rhinoceros matutinus Marsh, from Monmouth County.

$J$ nuary 24.-Mr. Vaux, Vice-President, in the chair. $-M$. Thomas Meehan presented a fruit of a pear, which presented the external appearance of an apple, gathered from a Tyson pear tree growing in the garden of Dr. Lawrence, of Paris, Canada. Dr. Lawrence had a Rhode Island greening apple near the pear tree, and some of the latter interlaced with it. The pear tree was full of blossoms last spring, but only those interlacing bore fruit. They had all the appearance of apples, so much so, that many who had seen them supposed there must have been some mistake as to Dr. Lawrence gathering them. Dr. L., had, however, when he first saw them, obtained Mrs. Lawrence's aid in separating the branches, so that there should be no mistaize. The specimens had been sent to Mr. Meehan, who regarcled them as apples; but on cutting them open, found the seed to be of the pear. The granular matter characteristic of the pulp of the pear also existed in the carpels, but none in the pulp, which was wholly fibrous, as in the apple; the insertion of the stalk, also, was that of the pear. Instead of the cavity being funnelshaper, as in the apple, it was campanulate, as if the stem had been pushed in, carrying the epidermis and pulp with it. $\mathrm{He}$ had no doubt that the fruit had the pedicel, carpellary walls, and seeds of the pear, with the granular pear-pulp wanting; but with the fibrous pulp and epiderm of the apple. As to the law of its production, he disliked speculation, but it would seem that there were two ways in which it might be producedeither by a natural evolution of form, independent of sexual influence, which plants at times exhibited, or by crossfertilisation with the apple. In the latter case, if found true, it would have an important bearing on the question often mooted, whether cross-fertilisation effected change immediately in the fruit impregnated, or whether change only appeared after the germinetion of the impregnated seeds. In the case of varieties of Indian com, we know the change is immediate; and it was generally believed some cucurbitaceous plants furni-hed similar facts; but he thought it had not been known in other plants, especially in the case of species as distinct as the apple and pear.

\section{BOOKS RECEIVED}

ENGLish.-The Micrographic Dictionary: Griffth and Henfrey; New Edition, Parts $x$ and 2 (London: Van Voorst). - Homo versus. Darvin (London: Hamilton and Co.).-Notes on Comparative Anatomy: W. M. Ord (London: Churchili)

YOREIGN- (Through Williams and Norgate). -Neues Handwörterbuch der Chemie: Dr. Herman v. Fehling: Erster Band, Ite u. ate Lieierung.

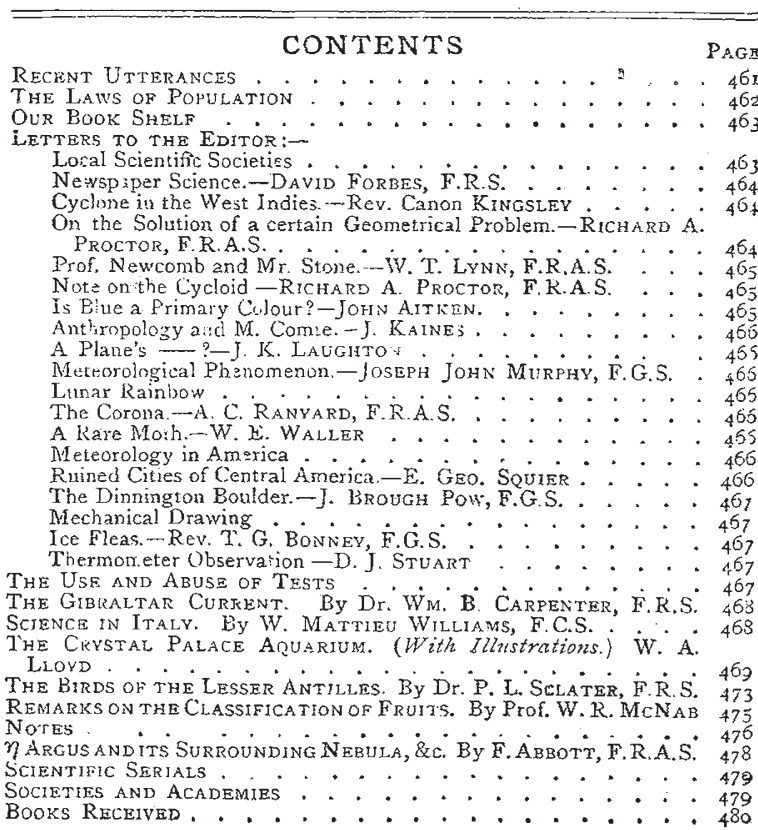

